\title{
Effects of feeding a quebracho-chestnut tannin extract on lactating cow performance and nitrogen utilization efficiency
}

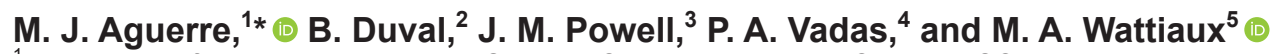 \\ ${ }^{1}$ Department of Animal and Veterinary Science, Clemson University, Clemson, SC 29634 \\ ${ }^{2}$ Department of Biology, New Mexico Institute of Mining and Technology, Socorro 87801 \\ ${ }^{3}$ US Dairy Forage Research Center, USDA Agricultural Research Service, Madison, WI 53706 \\ ${ }^{4}$ USDA Agricultural Research Service Office of National Programs, Beltsville, MD 20705 \\ ${ }^{5}$ Department of Dairy Science, University of Wisconsin, Madison 53706
}

\section{ABSTRACT}

The effects of feeding a quebracho-chestnut tannin extract mixture on performance and nitrogen $(\mathrm{N})$ utilization were assessed with 36 multiparous lactating Holstein cows (mean \pm standard deviation; $706 \pm 59 \mathrm{~kg}$ of body weight; $126 \pm 20 \mathrm{~d}$ in milk) randomly assigned to 3 dietary treatments in a randomized complete block design. Following a 2 -wk covariate adjustment period, cows were fed their assigned treatment diets for 13 wk. Rice hulls were removed from a total mixed ration with a 54:46 forage:concentrate ratio (\% of dry matter; $\mathrm{DM})$, and a tannin extract mixture from quebracho and chestnut trees (2:1 ratio) was included at $0,0.45$, and $1.80 \%$ of dietary DM. There was no interaction between dietary treatments and experimental week for the reported measurements except milk lactose percentage. Overall, treatments did not affect milk yield $(48.6 \pm 7.8 \mathrm{~kg} / \mathrm{d})$, fat- and protein-corrected milk (46.1 $\pm 7.6 \mathrm{~kg} / \mathrm{d})$, milk fat content $(3.88 \pm 0.65 \%)$ and yield $(1.85 \pm 0.38 \mathrm{~kg} / \mathrm{d})$, and true protein yield $(1.45 \pm 0.21$ $\mathrm{kg} / \mathrm{d}$ ). However, incremental levels of tannin extracts in the diet produced a linear increase in DM intake (29.2 to $30.9 \mathrm{~kg} / \mathrm{d})$ and a linear decrease in kilograms of milk per kilogram of DM intake (1.67 to $1.57 \mathrm{~kg} / \mathrm{kg}$ ) and MUN (12.2 to $10.8 \mathrm{mg} / \mathrm{dL}$ ). Furthermore, there was a quadratic effect of tannin extracts on milk true protein content $(2.96,3.13$, and $3.00 \%$ for $0,0.45$, and $1.80 \%$ tannin extract, respectively) and a tendency for linear and quadratic response for body weight gain $(0.31,0.16$, and $0.44 \mathrm{~kg} / \mathrm{d}$ for $0,0.45$, and $1.80 \%$ tannin, respectively). Intake of $\mathrm{N}$ increased linearly (782, 795 , and $820 \mathrm{~g} / \mathrm{d}$ ) and $\mathrm{N}$ utilization efficiency (milk N/ intake $\mathrm{N})$ decreased linearly $(0.300,0.301$, and 0.275 for $0,0.45$, and $1.80 \%$ tannin, respectively). Relative to the

Received August 12, 2019.

Accepted November 1, 2019.

*Corresponding author: maguerr@clemson.edu
$0 \%$ diet, $1.80 \%$ tannin extract reduced estimated urinary $\mathrm{N}$ excretion by $11 \%$. In this study, adding $0.45 \%$ tannin extract to the diet reduced feed efficiency but had a positive effect on milk protein content. Feeding a tannin extract mixture from quebracho and chestnut may reduce environmental labile urinary $\mathrm{N}$ excretion without affecting milk yield but at the expense of a lower feed utilization efficiency.

Key words: tannin, nitrogen, dairy cow

\section{INTRODUCTION}

Tannins are naturally occurring plant polyphenols, broadly classified into hydrolyzable and condensed tannins (Mueller-Harvey, 2006). Hydrolyzable tannins are polyphenolic units esterified to a carbohydrate core, whereas condensed tannins (proanthocyanidins) are polymers of covalently bonded flavanols (i.e., catechin, epicatechin, gallocatechin, and epigallocatechin). Tannins have multiple phenolic hydroxyl groups that lead to the formation of tannin-protein complexes through hydrogen bonds, which are stable in the rumen $(\mathrm{pH}$ 5.0-7.0) and resistant to rumen microbial degradation but dissociate in the low-pH environment of the abomasum (Makkar, 2003). Furthermore, Waghorn et al. (1994) reported an increase in the flow of AA to the intestines when sheep were fed Lotus corniculatus, a legume containing condensed tannins. Supplementation of tannin extracts has been reported to exert beneficial effects in ruminants by reducing ruminal protein degradation and excretion of environmental labile urinary N (Ahnert et al., 2015), decreasing bloat potential in grazing cattle (Min et al., 2012), increasing antioxidant enzyme activities in plasma and liver (Liu et al., 2013), and reducing gastrointestinal parasitic infestation (Mueller-Harvey, 2006). Conversely, quebracho tannins may reduce nutrient digestibility by inhibiting digestive enzymes and rumen microbial activity and growth (Ahnert et al., 2015). The variable effects of tannin extracts reported in the literature are probably asso- 
ciated with ruminant species, adaptation time to the diets, type of tannins, and dose.

Several studies have shown positive effects of $L$. corniculatus and sainfoin (Onobrychis viciifolia) on milk production in sheep (Wang et al., 1996) and dairy cows (Huyen et al., 2016). However, tannins can also reduce breakdown of protected protein and absorption of AA in the intestine (Waghorn, 2008). Similarly, studies have shown no effect on performance when tannin extracts from quebracho or chestnut trees $(2$ common sources of condensed and hydrolyzable tannin) are fed to dairy cattle (Sliwinski et al., 2004; Dschaak et al., 2011; Henke et al., 2017). In a previous short-term study (Aguerre et al., 2016), we observed a tendency for higher milk protein content at low quebracho-chestnut tannin extract level $(0.45 \%$ of diet DM) but detrimental effects at higher levels of tannin inclusion $(0.90$ and $1.80 \%$ of diet $\mathrm{DM}$ ) as indicated by lower DMI, milk protein content and yield, and overall apparent nutrient digestibility. Recent studies have suggested that some nitrogen (N)related responses, such as milk protein, require more than 3 wk of adaptation for stabilization (Zanton, 2016; Barros et al., 2017). Furthermore, reported responses to extracts containing hydrolyzable tannin that are rumen degradable (Waghorn, 2008) might have been affected by insufficient adaptation time for the microbial population, particularly when fed at higher doses. Thus, long-term feeding of tannin extracts might lead to an adaptation to these compounds and a reduction of their effects on animal performance.

Therefore, before tannins can be added to dairy cow diets, there is a need to determine the balance between an effective and a deleterious dose of quebracho-chestnut tannin extract on the performance of lactating dairy cows fed these extracts for extended periods of time. We hypothesized that long-term feeding of tannin extracts would increase milk protein content without affecting animal performance. Furthermore, we hypothesized that long-term adaptation would mitigate the negative effects of tannin extracts on animal performance observed in short-term studies. Thus, our objective was to determine the dose response to quebracho-chestnut tannin extract mixes fed over a 13 -wk period on lactating cow performance and $\mathrm{N}$ utilization efficiency when incorporated at a level that we expected would bring beneficial effect $(0.45 \%$ of diet DM) and detrimental effects $(1.80 \%$ of diet DM).

\section{MATERIALS AND METHODS}

This study was conducted as part of an experiment that evaluated the effects of long-term feeding of tannin extracts on animal performance and gaseous emission from lactating dairy cows. A companion article has discussed the effect of long-term feeding of tannin extracts on cow methane emission and manure ammonia emission (Duval et al., 2016). In contrast, this publication focuses on milk production and composition and $\mathrm{N}$ utilization efficiency. The Institutional Animal Care and Use Committee of the College of Agricultural and Life Sciences of the University of Wisconsin-Madison approved the experimental protocol for this study.

\section{Animals and Treatments}

Thirty-six multiparous lactating Holstein cows (mean $\pm \mathrm{SD} ; 706 \pm 59 \mathrm{~kg}$ of BW; $126 \pm 20$ DIM; $53.8 \pm 7.7$ $\mathrm{kg}$ milk yield) were randomly assigned to dietary treatments in a study designed as a randomized complete block. Diets containing 54\% forage (DM basis) were formulated to be isonitrogenous and to meet the vitamin and mineral guidelines of NRC (2001) for cows producing on average $50.0 \mathrm{~kg}$ of milk/d. The dietary ingredients, which were typical for the Midwestern United States, are listed in Table 1. Following a 2-wk covariate adjustment period (Table 1), cows were fed 1 of 3 dietary treatments including $0,0.45$, or $1.80 \%$ (DM basis) of a tannin extract from quebracho (Schinopsis spp.) and chestnut (Castanea sativa) trees for $13 \mathrm{wk}$ (91 d). Rice hulls was replaced proportionally to the tannin included in the diet (Table 1). The tannin extract (Bypro; SilvaTeam, Indunor S.A., Buenos Aires, Argentina) contained (by weight) one-third chestnut tannin extract and two-thirds quebracho tannin extract. Quebracho and chestnut extracts were separately analyzed using MALDI-TOF MS according to Pizzi et al. (2009). Analysis of the quebracho extract by MALDI-TOF indicated the following composition (DM basis): $84.3 \%$ condensed flavan-3-ols (predominantly profisetinidin), $10.7 \%$ oligomers of flavan-3-ols (catechin and epicatechin dimers), and $5 \%$ carbohydrates derivate (dimers of pentose, monocarboxylic acid of hexose, and 6-carbon sugars). The MALDI-TOF chestnut extract analysis indicated the following composition (DM basis): $7.9 \%$ digalloyl glucose, $5.0 \%$ trigalloyl glucose, $16.5 \%$ pentagalloyl glucose, and $70.6 \%$ oligomers of digalloyl glucose, trigalloyl glucose, and pentagalloyl glucose. Additional chestnut extract structure can be found in Pizzi et al. (2009).

Cows were housed in tiestall barns bedded with rubber mats with chopped wheat straw as bedding and had free access to water throughout the experiment. Diets were offered as TMR once daily at $0700 \mathrm{~h}$, allowing for 5 to $10 \%$ orts. The ingredient mix was adjusted based on weekly forage DM analysis.

Data collected for this study occurred concurrently with the study of Duval et al. (2016) in which the 36 cows were blocked into 4 groups of 9 cows ( 3 cows per 
treatments) for methane emission measurements. Thus, each block started the trial $1 \mathrm{wk}$ apart from the previous one. Data reported here included those obtained from cows used for gas emission measurements $(\mathrm{n}=$ 12 ) and were from the last $3 \mathrm{~d}$ of a 7 -d period when cows were housed in the chambers (see details in Duval et al., 2016).

\section{Feed and Milk Sampling and Analyses}

Daily samples of approximately $0.5 \mathrm{~kg}$ each of silage, high-moisture shelled corn, each TMR, and orts were collected and stored at $-20^{\circ} \mathrm{C}$. Samples of canola meal, roasted soybeans, dry distillers grain with solubles, rice hulls, and tannin extract mixture were collected weekly. Individual feed samples were dried at $55^{\circ} \mathrm{C}$ (forced-air oven) for $48 \mathrm{~h}$ and ground to pass a 1-mm Wiley mill screen (Arthur H. Thomas, Philadelphia, PA). Ground samples collected in 4 consecutive weeks were pooled to create monthly samples, which were analyzed for analytical DM at $105^{\circ} \mathrm{C}$ for $24 \mathrm{~h}$ and ash (method 942.05; AOAC International, 2006). In addition, these composite feed samples were analyzed at Dairyland Laboratories Inc. (Arcadia, WI) for CP (method 990.03; AOAC International, 2006), NDF using $\alpha$-amylase and sodium sulfite and corrected for ash concentration (Van Soest et al., 1991), and starch (Knudsen, 1997; modified by analyzing glucose using a YSI Biochemistry Analyzer; YSI Inc., Yellow Springs, OH). Furthermore, 30-h in vitro ruminal NDF digestibility and DM digestibility were determined in the pooled alfalfa and corn silage samples by the same commercial laboratory using the method of Goering and Van Soest (1970), with the modification that the inoculum was a composite containing strained ruminal fluid and blended ruminal solids. Nonfiber carbohydrate was calculated as 100 $-(\mathrm{NDF}+$ ether extract $+\mathrm{CP}+$ ash $)$, where ether extract was from Table 15.1 of NRC (2001). Chemical composition of the diets was computed from analytical results and the proportion of feed ingredients in the TMR. Individual-cow DMI was computed weekly based on daily records of TMR offered and refused and the $105^{\circ} \mathrm{C} \mathrm{DM}$ contents of the TMR and orts.

Milk production was recorded on each cow at each of the 3 daily milkings $(0400,1130$, and $1900 \mathrm{~h})$ throughout the study and averaged on a weekly basis. Milk samples from 6 consecutive milkings were collected weekly and individually analyzed for fat, true protein, lactose, SNF, and MUN using infrared analysis (AgSource Milk Analysis Laboratory, Menomonie, WI) with a Foss FT6000 (Foss North America Inc., Eden Prairie, MN). Average daily concentration and yield of

Table 1. Ingredient and chemical composition of covariate and dietary treatments

\begin{tabular}{|c|c|c|c|c|}
\hline \multirow[b]{2}{*}{ Item } & \multirow[b]{2}{*}{ Covariate } & \multicolumn{3}{|c|}{ Tannin level, $\%$ of DM } \\
\hline & & 0 & 0.45 & 1.80 \\
\hline \multicolumn{5}{|c|}{ Ingredient composition, $\%$ of DM } \\
\hline Alfalfa silage & 22.5 & 22.5 & 22.4 & 22.4 \\
\hline Corn silage & 28.5 & 32.6 & 32.6 & 32.6 \\
\hline High-moisture corn & 24.9 & 20.1 & 20.1 & 20.1 \\
\hline Canola meal & 9.2 & 8.6 & 8.6 & 8.6 \\
\hline Soybean roasted & 8.1 & 7.9 & 7.9 & 7.9 \\
\hline Corn distillers grains & 4.2 & 4.2 & 4.2 & 4.2 \\
\hline Rice hulls & - & 1.8 & 1.35 & - \\
\hline Tannin extract & - & - & 0.45 & 1.8 \\
\hline Vitamin and mineral $\operatorname{mix}^{1}$ & 2.5 & 2.5 & 2.5 & 2.5 \\
\hline \multicolumn{5}{|l|}{ Chemical composition } \\
\hline $\mathrm{DM}$, as is & 49.9 & 49.9 & 50.3 & 50.4 \\
\hline $\mathrm{OM}^{2} \%$ of $\mathrm{DM}$ & 91.7 & 91.9 & 91.5 & 90.4 \\
\hline $\mathrm{CP}, \%$ of DM & 16.9 & 16.6 & 16.6 & 16.6 \\
\hline $\mathrm{RDP}^{3} \%$ of $\mathrm{DM}$ & - & 11.1 & 11.0 & 11.0 \\
\hline $\mathrm{RUP}^{3} \%$ of DM & - & 5.5 & 5.6 & 5.6 \\
\hline NDF, $\%$ of DM & 29.8 & 32.8 & 32.4 & 31.3 \\
\hline $\mathrm{NFC},{ }^{4} \%$ of $\mathrm{DM}$ & 40.0 & 43.1 & 43.4 & 44.6 \\
\hline Starch, $\%$ of DM & 27.1 & 24.8 & 24.8 & 24.7 \\
\hline Ether extract, $\%$ of DM & 4.8 & 4.8 & 4.8 & 4.8 \\
\hline $\mathrm{NE}_{\mathrm{L}}, \mathrm{Mcal} / \mathrm{kg}$ & 1.58 & 1.58 & 1.58 & 1.55 \\
\hline \multicolumn{5}{|c|}{$\begin{array}{l}{ }^{1} \text { Premix composition (guaranteed minimum concentration; as-fed basis): Ca } 14.7 \% \text {, salt } 10.3 \%, \mathrm{Na} 13.9 \% \text {, M, } \\
4.5 \% \text {, K } 0.4 \% \text {, S } 0.9 \% \text {, Se } 14 \mathrm{mg} / \mathrm{kg} \text {, vitamin A } 282,192 \mathrm{IU} / \mathrm{kg} \text {, vitamin D } 55,116 \mathrm{IU} / \mathrm{kg} \text {, vitamin E 1,334 IU } \\
\mathrm{kg} \text {, and monensin } 440 \mathrm{~g} / \mathrm{t} . \\
{ }^{2} \mathrm{OM}=100-\text { ash. } \\
{ }^{3} \mathrm{Calculated} \text { using measured DMI, BW, milk production, and composition and feed analyses (NRC, 2001). } \\
{ }^{4} \mathrm{NFC}=100-(\% \mathrm{NDF}+\% \mathrm{CP}+\% \text { ether extract }+\% \text { ash), using tabular values for ether extract (NRC } \\
2001) .\end{array}$} \\
\hline
\end{tabular}


milk components were computed using morning, midday, and evening milk production as weighting factor. Yield of fat- and protein-corrected milk (FPCM) was calculated as milk $(\mathrm{kg} / \mathrm{d}) \times[0.1226 \times$ fat $(\%)+0.0776$ $\times$ true protein $(\%)+0.2534]$ according to IDF (2015). Feed efficiencies were computed as the yields of milk and FPCM divided by DMI. Efficiency of dietary N utilization was calculated as [milk true protein $(\mathrm{kg}) / 6.38] /$ [DMI $(\mathrm{kg}) \times$ dietary CP $(\%) / 6.25]$.

\section{Cow BW and Urine N Excretion}

Body weight was recorded for each cow on 3 consecutive days weekly starting the last week of the covariate period. Body weight change of each cow was determined by regression of the BW measurements over time using an Excel spreadsheet (Microsoft Corp., Redmond, WA). Predicted urinary $\mathrm{N}$ excretion was calculated as urinary $\mathrm{N}(\mathrm{g} / \mathrm{d})=0.0283 \times \mathrm{BW}(\mathrm{kg}) \times \mathrm{MUN}(\mathrm{mg} /$ $\mathrm{dL}$ ). This equation was selected in part because it was derived from cows belonging to the same herd and fed diets with similar ingredients and dietary composition (Wattiaux and Karg, 2004). Several studies have proven MUN to be a reliable predictor of urinary total $\mathrm{N}$ and urea N (Kauffman and St-Pierre, 2001; Kohn et al., 2002; Barros et al., 2019).

\section{Statistical Analysis}

Data were analyzed with the Mixed procedure of SAS (2008) for a randomized complete block design with a covariate adjustment. Dry matter intake, milk yield, milk composition, and $\mathrm{N}$ utilization efficiency data were analyzed using the following model:

$$
Y_{i j k l}=\mu+\operatorname{Cov}_{i}+B_{j}+T_{k}+C_{i: k}+W_{l}+T W_{k l}+e_{i j k l}
$$

where $Y_{i j k l}$ is the dependent variable, $\mu$ is the overall mean, $\operatorname{Cov}_{i}$ is the covariate effect, $B_{j}$ is the effect of the $j$ th block ( $j=1$ to 4$), T_{k}$ is the effect of the $k$ th dietary treatment ( $k=1$ to 3 ), $C_{i: k}$ is the effect of the $i$ th cow ( $i=1$ to 36 ) within the $k$ th dietary treatment, $W_{l}$ is the effect of the repeated measure in the $l$ th week $(l=1$ to 13), $T W_{k l}$ is the interaction effect between the $k$ th dietary treatments and the $l$ th week, and $e_{i j k l}$ is the residual error $\sim N\left(0, \sigma_{e}^{2}\right)$, where $\sigma_{e}^{2}$ is the error variance. All terms were considered fixed except for block, cow within dietary treatment, and residual error, which were considered random. The first-order autoregressive covariance structure was used to fit a time series-type covariance structure in which the correlation declines as a function of time. Degrees of freedom were calculated using the Kenward-Roger option. Body weight change data were analyzed using the model described above but without the covariance or repeated measures.

Preplanned orthogonal polynomial contrasts were used to test for linear and quadratic effects of tannin level in the diet. Significance was declared at $P \leq 0.05$ and a tendency at $0.05<P \leq 0.10$. When a quadratic effect was declared, the response variable was regressed on dietary tannin content to obtain regression equation coefficients, which were used to predict maximal response and corresponding dietary tannin content. When repeated measurements exhibited a significant dietary treatment $\times$ week interaction, the nature of the interaction was explored using the SLICE option.

\section{RESULTS AND DISCUSSION}

Two cows were removed from the study (both at wk 4) because of health issues unrelated to the dietary treatments. One cow $(0.45 \%$ tannin extract treatment) was removed due to mastitis, and another ( $0 \%$ tannin extract treatment) died due to a rupture of a pulmonary artery. Data from these cows were not included in the statistical analyses. The interaction between dietary treatment and experimental week did not reach significance $(P=0.32$ to 0.99$)$ for any of the measurements reported (Tables 3 and 4 ), except milk lactose percentage $(P=0.05)$. This interaction was due to greater weekly variation in the $0 \%$ tannin diet compared with the tannin-containing diets (data not shown).

\section{Diet Chemical Composition}

The proportion of each ingredient and chemical composition of the dietary treatments are shown in Table 1, and the chemical composition of dietary ingredients is shown in Table 2. Based on Table 15.1 of NRC (2001), the quality of the corn silage was "normal," whereas alfalfa silage was "immature to mid-mature." Increasing the concentration of tannin extracts in the diet at the expense of rice hulls had limited effect on DM, OM, $\mathrm{CP}, \mathrm{NDF}$, and starch, which averaged (as \% of DM) $50.2,91.3,16.6,32.2$, and 24.8 , respectively. The NRC (2001)-predicted RDP, RUP, and $\mathrm{NE}_{\mathrm{L}}$ were similar across dietary treatments and averaged $11.0 \%$ of DM, $5.6 \%$ of $\mathrm{DM}$, and $1.57 \mathrm{Mcal} / \mathrm{kg}$ of $\mathrm{DM}$, respectively. These values were computed using ingredient composition, feed analyses, and individual cow traits (BW and DIM) and performance (DMI, milk yield, and composition). The NRC (2001)-predicted MP supply averaged $2,843,3,061$, and $3,150 \mathrm{~g} / \mathrm{d}$ and was $9.7,7.6$, and $2.2 \%$ deficient in the $0,0.45$, and $1.80 \%$ tannin diets, respectively. These values varied across treatments not because of differences in dietary chemical composition 
Table 2. Chemical composition of dietary ingredients ${ }^{1}$

\begin{tabular}{lrrrrrr}
\hline Item & AS & CS & HMSC & DDG & CM & RSB \\
\hline DM, \% & 37.5 & 35.1 & 69.8 & 91.0 & 91.5 & 95.7 \\
Ash, \% of DM & 11.3 & 4.1 & 1.4 & 5.4 & 8.0 & 5.4 \\
CP, \% of DM & 22.3 & 7.3 & 7.2 & 30.4 & 41.1 & 37.6 \\
NDF, \% of DM & 38.4 & 48.6 & 6.8 & 29.0 & 28.6 & 22.9 \\
NFC, \% of DM & 25.8 & 36.8 & 80.4 & 25.2 & 16.9 & 15.1 \\
Starch, \% of DM & 2.5 & 27.1 & 74.4 & 4.6 & 1.3 & 0.9 \\
IVDMD $_{30}$, \% of DM & 78.0 & 79.9 & - & - & - & - \\
NDFD $_{30}, \%$ of NDF & 42.5 & 58.5 & - & - & - & - \\
\hline
\end{tabular}

${ }^{1} \mathrm{AS}=$ alfalfa silage; $\mathrm{CS}=$ corn silage; HMSC $=$ high-moisture shell corn; $\mathrm{DDG}=$ dry distillers grain; $\mathrm{CM}=$ canola meal; $\mathrm{RSB}=$ roasted soybeans.

${ }^{2} \mathrm{NFC}=100-(\% \mathrm{NDF}+\% \mathrm{CP}+\%$ ether extract $+\%$ ash $)$, using NRC (2001) tabular values for ether extract.

${ }^{3}$ Dairyland Laboratories Inc. (Arcadia, WI). IVDMD ${ }_{30}=30$-h in vitro ruminal DM digestibility; $\mathrm{NDFD}_{30}=30$-h in vitro ruminal NDF digestibility.

(Table 1) but rather because of the effect of tannin extracts on DMI (Table 3).

\section{Intake, Milk Production, and Composition}

Table 3 presents the covariate-adjusted least squares means as well as the linear and quadratic effects of the level of tannin in the diet on BW, BCS, DMI, feed efficiencies, and milk production and composition. Despite a linear increase in DMI from 29.2 to $30.9 \mathrm{~kg} / \mathrm{d}$, milk yield $(48.6 \mathrm{~kg} / \mathrm{d})$ and FPCM (46.1 $\mathrm{kg} / \mathrm{d}$ ) were unaffected by increasing tannin content in the diet. Consequently, a linear decrease in milk/DMI and FPCM/DMI was observed with increasing level of tannin. Dschaak et al. (2011) observed that adding quebracho tannin at $3 \%$ of diet DM decreased DMI. However, Sliwinski et al. (2004) and Liu et al. (2013) reported no effect of chestnut tree extracts on DMI when fed at either 0.49 or $1 \%$ of dietary DM. Moreover, results from the current study contrasted with those of Aguerre et al. (2016), who found decreasing DMI and increasing feed utilization efficiency when a similar tannin extract mixture increased from 0 to $1.80 \%$ of the diet in a short-term study. Despite a low digestibility and nutritive value $(2.3 \% \mathrm{CP}$ and $79.9 \% \mathrm{NDF}$, DM basis), a negative effect of adding rice hulls to the diet was unlikely, as Tillman et al. (1969) reported that feeding rice hulls at up to $9 \%$ of dietary DM to finishing beef cattle did not decrease DMI or DM digestibility. However, due to the high DMI observed in this study, rice hull intake $(0.56 \mathrm{~kg}$ on the $0 \%$ tannin diet) cannot be completely disregarded as the reason for the increase in DMI with incremental levels of tannin. In contrast, cows fed the $0.45 \%$ tannin diet consumed $0.136 \mathrm{~kg}$ of rice hulls/d (DM basis).

Milk fat and lactose content $(\%)$ and yield $(\mathrm{kg} / \mathrm{d})$ were not affected by the concentration of tannin extract in the diet (Table 3). A quadratic response (y $\left.=-0.2634 \mathrm{x}^{2}+0.4963 \mathrm{x}+2.96\right)$ indicated that milk protein concentration reached a predicted maximum at $3.19 \%$ when tannin concentration was $0.94 \%$ of dietary

Table 3. Covariate-adjusted LSM and linear (L) and quadratic (Q) effects of the level of tannin in the diet on DMI, milk composition and production, feed efficiencies, and BW

\begin{tabular}{|c|c|c|c|c|c|c|}
\hline \multirow[b]{2}{*}{ Item } & \multicolumn{3}{|c|}{ Tannin, $\%$ of DM } & \multirow[b]{2}{*}{$\mathrm{SEM}^{1}$} & \multicolumn{2}{|c|}{$P$-value } \\
\hline & 0 & 0.45 & 1.80 & & $\mathrm{~L}$ & $\mathrm{Q}$ \\
\hline DMI, $\mathrm{kg} / \mathrm{d}$ & 29.2 & 30.1 & 30.9 & 0.59 & $<0.01$ & 0.35 \\
\hline Milk, kg/d & 48.8 & 49.0 & 48.3 & 1.00 & 0.53 & 0.70 \\
\hline $\mathrm{FPCM}^{2}, \mathrm{~kg} / \mathrm{d}$ & 46.0 & 46.8 & 45.8 & 1.48 & 0.76 & 0.60 \\
\hline \multicolumn{7}{|l|}{ Milk composition } \\
\hline Fat, $\%$ & 3.75 & 3.97 & 3.92 & 0.12 & 0.40 & 0.26 \\
\hline True protein, $\%$ & 2.96 & 3.13 & 2.99 & 0.04 & 0.58 & $<0.01$ \\
\hline Lactose, ${ }^{3} \%$ & 4.78 & 4.81 & 4.81 & 0.05 & 0.74 & 0.70 \\
\hline MUN, mg/dL & 12.2 & 12.1 & 10.8 & 0.19 & $<0.01$ & 0.27 \\
\hline \multicolumn{7}{|l|}{ Milk components yield } \\
\hline Fat, $\mathrm{kg} / \mathrm{d}$ & 1.83 & 1.89 & 1.85 & 0.07 & 0.89 & 0.49 \\
\hline True protein, kg/d & 1.44 & 1.50 & 1.41 & 0.04 & 0.29 & 0.12 \\
\hline Lactose, $\mathrm{kg} / \mathrm{d}$ & 2.28 & 2.27 & 2.24 & 0.10 & 0.58 & 0.98 \\
\hline \multicolumn{7}{|l|}{ Feed efficiency ${ }^{4}$} \\
\hline Milk/DMI & 1.67 & 1.63 & 1.57 & 0.04 & 0.01 & 0.64 \\
\hline FPCM/DMI & 1.58 & 1.55 & 1.48 & 0.04 & 0.02 & 0.91 \\
\hline $\mathrm{BW}, \mathrm{kg}$ & 725 & 716 & 729 & 4.67 & 0.25 & 0.10 \\
\hline BW change, $\mathrm{kg} / \mathrm{d}$ & 0.31 & 0.16 & 0.44 & 0.08 & 0.07 & 0.06 \\
\hline
\end{tabular}

${ }^{1}$ When the number of observations was different between treatments, the highest SE was reported.

${ }^{2}$ Fat- and protein-corrected milk $(\mathrm{FPCM})=\operatorname{milk}(\mathrm{kg} / \mathrm{d}) \times[0.1226 \times$ fat $(\%)+0.0776 \times$ protein $(\%)+0.2534]$ (IDF, 2015).

${ }^{3}$ Treatment by week interaction $(P=0.05)$.

${ }^{4}$ Efficiencies calculated as milk $(\mathrm{kg} / \mathrm{d})$ or FPCM $(\mathrm{kg} / \mathrm{d})$ divided by DMI $(\mathrm{kg} / \mathrm{d})$. 
DM. In a previous study (Aguerre et al., 2016), we observed a tendency $(P=0.06)$ for a quadratic response of milk protein content (predicted maximum at $2.89 \%$ when tannin concentration was $0.47 \%$ ). Results from this study confirmed the small beneficial effects on milk protein content at low tannin levels that we previously observed (Aguerre et al., 2016). However, most lactation studies have shown no changes in concentration and yield of milk protein or other components when quebracho or chestnut tannin extracts were added to the diet (Sliwinski et al., 2004; Benchaar et al., 2008; Dschaak et al., 2011). In this study, protein yield was not affected by the level of tannin extract in the diet.

Increased lactation performance (13.8 vs. $16.5 \mathrm{~kg} / \mathrm{d}$ ) has been reported when cows were fed temperate forages (Lotus corniculatus) containing $2.73 \%$ DM condensed tannins with or without polyethylene glycol drenching, respectively (Woodward et al., 1999). These observed improvements have been attributed to the protection of feed protein from degradation in the rumen, leading to increases in the flow and, eventually, absorption of EAA in the small intestine (Bermingham et al., 2001). Furthermore, Roy et al. (2004) reported an increase of mammary blood flow and supply of EAA in lactating sheep fed a legume (Sulla) containing $8 \%$ (forage DM) condensed tannin. Previous studies from our group (Aguerre et al., 2016) have shown that feeding chestnut-quebracho tannin extracts reduced ruminal $\mathrm{NH}_{3}-\mathrm{N}$, branched-chain VFA concentration, MUN, and urinary $\mathrm{N}$ excretion. However, under the conditions of this study, it was not possible to infer whether tannin extracts protected and increased the flow and absorption of MP in the small intestine and whether the additional MP was of high or low biological value for milk protein synthesis. In addition, despite a decrease in dietary protein degradation and increase in duodenal dietary protein flow, feeding tannin extracts from quebracho and chestnut has been shown to reduce ruminal microbial activity, resulting in a lower digestibility of feed fractions and overall microbial protein outflow (Aguerre et al., 2016; Henke et al., 2017).

Compared with Aguerre et al. (2016), the present study showed a stronger effect on milk protein content when tannins were fed at $0.45 \%$ of dietary DM. However, in both studies, the positive effect on milk protein content was not significant when tannin extracts were fed at levels $>0.45 \%$ of diet DM. One important difference between studies is the NRC (2001)-predicted RDP balance. In Aguerre et al. (2016), the predicted RDP balance was on average less than $1.0 \%$ in excess for all tannin-containing diets. However, in the present study, predicted RDP balance was $14 \%$ in excess for both tannin-containing diets. A possible explanation for the positive effects of the $0.45 \%$ tannin levels in the diet is that this particular dosage provides the conditions that increase the supply of digestible RUP without impeding the flow of microbial protein to the small intestine. In addition, our data suggested that these effects were enhanced by the presence of an excess of RDP in the diet but not by a higher tannin extract dosage. It is unclear why the milk protein content did not increase further between the 0.45 and $1.80 \%$ dietary tannin levels but essentially returned to the value observed for the $0 \%$ dietary tannin level (Table 3). However, it may be associated with a decreased supply of MP from reduced microbial protein or digestible RUP, or it may have been mediated through a decrease in energy supply as reflected in the linear decrease in efficiency measures (milk/DMI and FPCM/DMI) with increasing level of tannin in the diet (Table 3).

Although previous short-term studies have shown that ruminal bacteria can adapt to or digest (McSweeney et al., 2001) hydrolyzable tannins, the lack of treatment $\times$ time interaction under the conditions of this study suggested that any possible adjustments of ruminal microbiome and metabolism occurred within hours or days but not weeks after incorporating tannin extract in the diet at both 0.45 and $1.80 \%$ of dietary DM. Thus, no adaptation period appeared to be necessary when incorporating quebracho-chestnut extract in the diet of lactating dairy cows. However, this conclusion should be challenged in future studies to ascertain its veracity under other feeding conditions and, in particular, at different dietary RDP and RUP levels.

Average BW change tended to respond in a quadratic fashion to additional tannin extracts in the diet; the lowest BW gains were less than half for the $0.45 \%$ level compared with the 0 and $1.80 \%$ levels (Table 3 ). The reasons for this tendency remain unclear but might be related to a particular shift in ruminal VFA that occurred in association with the suggested change in ruminal N metabolism described above. Rivera-Méndez et al. (2017) reported an increase in steer weight gain (finishing phase) when quebracho or quebracho-chestnut extract were fed for $84 \mathrm{~d}$ at $0.6 \%$ of dietary DM. Other authors reported no effect of feeding diets with a wide range of quebracho or chestnut tannin concentrations on BW change in dairy (Dschaak et al., 2011) and beef (Aboagye et al., 2018) cattle.

\section{N Partitioning}

Nitrogen intake increased linearly with increasing levels of dietary tannin and was $4.9 \%$ greater for the $1.80 \%$ tannin extract level compared with the $0 \%$ tannin extract level (Table 4). This effect essentially was due to greater DMI as diets were isonitrogenous. Nitrogen use efficiency decreased by 2.5 percentage units 
from 30.0 to $27.5 \%$ with an increase in dietary tannin extract level from 0 to $1.80 \%$. This effect essentially was due to the increase in $\mathrm{N}$ intake as there was no change in milk $\mathrm{N}(232 \pm 27 \mathrm{~g} / \mathrm{d})$ among dietary treatments. In addition, feeding tannin extracts linearly reduced the predicted urinary $\mathrm{N}$ excretion by $11.2 \%$ from 250 to $222 \mathrm{~g} / \mathrm{d}$ when tannin extract level in the diet increased from 0 to $1.80 \%$. Earlier studies using tannin extracts from quebracho (Dawson et al., 1999; Ahnert et al., 2015) and quebracho-chestnut mixes (Aguerre et al., 2016) reported a decrease in urinary $\mathrm{N}$ excretion with incremental levels of extracts in the diet. This effect might be associated with the protein-binding properties of tannins that resulted in lower ruminal protein degradation (Aguerre et al., 2016), the improved EAA profile of MP (as discussed above), or a reduction in dietary protein degradation due to the inhibitory effect (e.g., inactivation of microbial enzymes) on some rumen microbial species (Dickhoefer et al., 2016). Results from this study strengthened earlier findings of the positive effects of feeding a quebracho-chestnut tannin extract in reducing the excretion of environmental labile urinary $\mathrm{N}$ and manure emission of $\mathrm{NH}_{3}$ from barn floors and soil (Powell et al., 2011a,b).

\section{CONCLUSIONS}

The tannin extract used in this study had distinct effects depending on its dosage. For example, milk protein content increased only when adding $0.45 \%$ tannin extracts to the diet. In contrast, BW gain tended to be enhanced only when the diet contained $1.8 \%$ tannin extract. In addition, increasing the level of tannin extract in the diet linearly increased DMI but decreased feed efficiency, $\mathrm{N}$ use efficiency, and predicted urinary $\mathrm{N}$ excretion with no effect on milk production. Our data suggested that there is no need for an adaptation period. Furthermore, feeding a tannin extract mixture from quebracho and chestnut at a level of $0.45 \%$ in the diet DM may reduce environmental labile urinary $\mathrm{N}$ excretion without affecting milk yield but at the expense of a lower feed utilization efficiency. Future work should be designed to confirm these findings and to investigate the long-term effects of tannin extract on $\mathrm{N}$ digestion and metabolism when cows are fed diets with varying levels of RDP and RUP.

\section{ACKNOWLEDGMENTS}

The authors thank Ron Skoyen and his barn crew at the US Dairy Forage Research Center for feeding and animal care. We also thank Sandra Bertics (Dairy Science Department, University of Wisconsin-Madison), Wendy Radloff, Kristine Niemann, Alicia Pelletier, and
Table 4. Covariate-adjusted LSM and linear (L) and quadratic (Q) effects of the level of tannin in the diet on nitrogen $(\mathrm{N})$ utilization

\begin{tabular}{lcccrrrrr}
\hline & \multicolumn{3}{c}{ Tannin, \% of DM } & & \multicolumn{2}{c}{$P$-value } \\
\cline { 2 - 4 } \cline { 7 - 8 } Item & 0 & 0.45 & 1.80 & SEM $^{1}$ & & $\mathrm{~L}$ & $\mathrm{Q}$ \\
\hline Intake N, g/d & 782 & 795 & 820 & & 15.8 & & 0.01 & 0.76 \\
Milk N, g/d & 231 & 240 & 225 & & 6.7 & 0.22 & 0.13 \\
Milk N/intake N, \% & 30.0 & 30.1 & 27.5 & & 0.7 & $<0.01$ & 0.30 \\
Urine N, & g/d & 250 & 244 & 222 & & 5.7 & $<0.01$ & 0.88 \\
\hline
\end{tabular}

${ }^{1}$ When the number of observations was different between treatments, the highest SE was reported.

${ }^{2}$ Urine $\mathrm{N}(\mathrm{g} / \mathrm{d})=0.0283 \times \mathrm{BW}(\mathrm{kg}) \times$ milk urea $\mathrm{N}(\mathrm{mg} / \mathrm{dL})($ Wattiaux and Karg, 2004).

Mary Becker (US Dairy Forage Research Center, Madison, WI) for assisting with laboratory analyses and SilvaTeam, Indunor S. A. (Buenos Aires, Argentina) for donating the Bypro extract. The authors have not stated any conflicts of interest.

\section{REFERENCES}

Aboagye, I. A., M. Oba, A. R. Castillo, K. M. Koenig, A. D. Iwaasa, and K. A. Beauchemin. 2018. Effects of hydrolyzable tannin with or without condensed tannin on methane emissions, nitrogen use, and performance of beef cattle fed a high-forage diet. J. Anim. Sci. 96:5276-5286. https://doi.org/10.1093/jas/sky352.

Aguerre, M. J., M. C. Capozzolo, P. Lencioni, C. Cabral, and M. A. Wattiaux. 2016. Effect of quebracho-chestnut tannin extracts at two dietary crude protein levels on performance, rumen fermentation and nitrogen partitioning in dairy cows. J. Dairy Sci. 99:4476-4486. https://doi.org/10.3168/jds.2015-10745.

Ahnert, S., U. Dickhoefer, F. Schulz, and A. Susenbeth. 2015. Influence of ruminal Quebracho tannin extract infusion on apparent nutrient digestibility, nitrogen balance, and urinary purine derivatives excretion in heifers. Livest. Sci. 177:63-70. https://doi.org/ 10.1016/j.livsci.2015.04.004.

AOAC International. 2006. Official Methods of Analysis. 18th ed. AOAC International, Washington, DC.

Barros, T., M. A. Quaassdorff, M. J. Aguerre, J. J. O. Colmenero, S. J. Bertics, P. M. Crump, and M. A. Wattiaux. 2017. Effects of dietary crude protein concentration on late-lactation dairy cow performance and indicators of nitrogen utilization. J. Dairy Sci. 100:5434-5448. https://doi.org/10.3168/jds.2016-11917.

Barros, T., K. F. Reed, J. J. Olmos Colmenero, and M. A. Wattiaux. 2019. Short communication: Milk urea nitrogen as a predictor of urinary nitrogen and urea nitrogen excretions of late-lactation dairy cows fed nitrogen-limiting diets. J. Dairy Sci. 102:1601-1607. https://doi.org/10.3168/jds.2018-14551.

Benchaar, C., T. A. McAllister, and P. Y. Chouinard. 2008. Digestion, ruminal fermentation, ciliate protozoal populations, and milk production from dairy cows fed cinnamaldehyde, quebracho condensed tannin, or Yucca schidigera saponin extract. J. Dairy Sci. 91:4765-4777. https://doi.org/10.3168/jds.2008-1338.

Bermingham, E. N., K. J. Hutchinson, D. K. Revell, I. M. Brookes, and W. C. McNabb. 2001. The effect of condensed tannins in sainfoin (Onobrychis viciaefolia) and sulla (Hedysarum coronarium) on the digestion of amino acids in sheep. Proc. N.Z. Soc. Anim. Prod. 61:116-119.

Dawson, J. M., P. J. Buttery, D. Jenkins, C. D. Wood, and M. Gill. 1999. Effects of dietary quebracho tannin on nutrient utilization and tissue metabolism in sheep and rats. J. Sci. Food Agric. 79:1423-1430. https://doi.org/10.1002/(SICI)1097 -0010(199908)79:11<1423::AID-JSFA383>3.0.CO;2-8. 
Dickhoefer, U., S. Ahnert, and A. Susenbeth. 2016. Effects of quebracho tannin extract on rumen fermentation and yield and composition of microbial mass in heifers. J. Anim. Sci. 94:1561-1575. https://doi.org/10.2527/jas.2015-0061.

Dschaak, C. M., C. M. Williams, M. S. Holt, J.-S. Eun, A. J. Young, and B. R. Min. 2011. Effects of supplementing condensed tannin extract on intake, digestion, ruminal fermentation, and milk production of lactating dairy cows. J. Dairy Sci. 94:2508-2519. https: //doi.org/10.3168/jds.2010-3818.

Duval, B. D., M. Aguerre, M. Wattiaux, P. A. Vadas, and J. M. Powell. 2016. Potential for reducing on-farm greenhouse gas and ammonia emissions from dairy cows with prolonged dietary tannin additions. Water Air Soil Pollut. 227:329. https://doi.org/10 .1007/s11270-016-2997-6.

Goering, H. K., and P. J. Van Soest. 1970. Forage fiber analysis. USDA Agric. Handbook No. 379. USDA Agricultural Research Service, Washington, DC.

Henke, A., U. Dickhoefer, E. Westreicher-Kristen, K. Knappstein, J. Molkentin, M. Hasler, and A. Susenbeth. 2017. Effect of dietary Quebracho tannin extract on feed intake, digestibility, excretion of urinary purine derivatives and milk production in dairy cows. Arch. Anim. Nutr. 71:37-53. https://doi.org/10.1080/1745039X 2016.1250541.

Huyen, N. T., O. Desrues, S. J. J. Alferink, T. Zandstra, M. W. A. Verstegen, W. H. Hendriks, and W. F. Pellikaan. 2016. Inclusion of sainfoin (Onobrychis viciifolia) silage in dairy cow rations affects nutrient digestibility, nitrogen utilization, energy balance, and methane emissions. J. Dairy Sci. 99:3566-3577. https://doi .org/10.3168/jds.2015-10583.

IDF (International Dairy Federation). 2015. A common carbon footprint approach for dairy: The IDF guide to standard lifecycle assessment methodology for the dairy sector. Bulletin no. 445. IDF, Brussels, Belgium.

Kauffman, A. J., and N. R. St-Pierre. 2001. The relationship of milk urea nitrogen to urine nitrogen excretion in Holstein and Jersey cows. J. Dairy Sci. 84:2284-2294. https://doi.org/10.3168/jds .S0022-0302(01)74675-9.

Knudsen, K. E. B. 1997. Carbohydrate and lignin contents of plant materials used in animal feeding. Anim. Feed Sci. Technol. 67:319 338. https://doi.org/10.1016/S0377-8401(97)00009-6.

Kohn, R. A., K. F. Kalscheur, and E. Russek-Cohen. 2002. Evaluation of models to estimate urinary nitrogen and expected milk urea nitrogen. J. Dairy Sci. 85:227-233. https://doi.org/10.3168/ jds.S0022-0302(02)74071-X.

Liu, H. W., D. W. Zhou, and K. Li. 2013. Effects of chestnut tannins on performance and antioxidative status of transition dairy cows. J. Dairy Sci. 96:5901-5907. https://doi.org/10.3168/jds.2013-6904.

Makkar, H. P. S. 2003. Effects and fate of tannins in ruminant animals, adaptation to tannins, and strategies to overcome detrimental effects of feeding tannin-rich feeds. Small Rumin. Res. 49:241-256. https://doi.org/10.1016/S0921-4488(03)00142-1.

McSweeney, C. S., B. Palmer, D. M. McNeill, and D. O. Krause. 2001. Microbial interactions with tannins: Nutritional consequences for ruminants. Anim. Feed Sci. Technol. 91:83-93. https://doi.org/10 .1016/S0377-8401(01)00232-2.

Min, B. R., W. E. Pinchak, K. Hernandez, C. Hernandez, M. E. Hume, E. Valencia, and J. D. Fulford. 2012. Effects of plant tannin supplementation on animal responses and in vivo ruminal bacterial populations associated with bloat in heifers grazing wheat forage. Prof. Anim. Sci. 28:464-472. https://doi.org/10.15232/S1080 -7446(15)30386-7.

Mueller-Harvey, I. 2006. Unravelling the conundrum of tannins in animal nutrition and health. J. Sci. Food Agric. 86:2010-2037. https: //doi.org/10.1002/jsfa.2577.

National Research Council. 2001. Nutrient Requirements of Dairy Cattle. 7th rev. ed. Natl. Acad. Press, Washington, DC.

Pizzi, A., H. Pasch, K. Rode, and S. Giovando. 2009. Polymer structure of commercial hydrolysable tannins by matrix assisted laser desorption ionization time of flight mass spectrometry. J. Appl. Polym. Sci. 113:3847-3859. https://doi.org/10.1002/app.30377.

Powell, J. M., M. J. Aguerre, and M. A. Wattiaux. 2011a. Tannin extracts abate ammonia emissions from simulated dairy barn floors. J. Environ. Qual. 40:907-914. https://doi.org/10.2134/jeq2010 .0492.

Powell, J. M., M. J. Aguerre, and M. A. Wattiaux. 2011b. Dietary crude protein and tannin impact dairy manure chemistry and ammonia emissions from incubated soils. J. Environ. Qual. 40:17671774. https://doi.org/10.2134/jeq2011.0085.

Rivera-Méndez, C., A. Plascencia, N. Torrentera, and R. A. Zinn. 2017. Effect of level and source of supplemental tannin on growth performance of steers during the late finishing phase. J. Appl Anim. Res. 45:199-203. https://doi.org/10.1080/09712119.2016 .1141776.

Roy, N. C., B. R. Sinclair, B. Treloar, A. Kirk, J. Peters, M. Tavendale, and W. C. McNabb. 2004. The effects of condensed tannins in sula (Hedysarum coronarium) on valine kinetics in the ovine mammary gland. Anim. Prod. Aust. 25:148-151.

SAS Institute. 2008. SAS/STAT User's Guide. Release 9.2. SAS Inst. Inc., Cary, NC.

Sliwinski, B. J., M. Kreuzer, F. Sutter, A. Machmuller, and H. R. Wettstein. 2004. Performance, body nitrogen conversion and nitrogen emission from manure of dairy cows fed diets supplemented with different plant extracts. J. Anim. Feed Sci. 13:73-91. https://doi .org/10.22358/jafs/67390/2004

Tillman, A. D., R. D. Furr, K. R. Hansen, L. B. Sherrod, and J. D. Word Jr.. 1969. Utilization of rice hulls in cattle finishing rations. J. Anim. Sci. 29:792-796. https://doi.org/10.2527/jas1969 $.295792 x$.

Van Soest, P. J., J. B. Robertson, and B. A. Lewis. 1991. Methods for dietary fiber, neutral detergent fiber, and nonstarch polysaccharides in relation to animal nutrition. J. Dairy Sci. 74:3583-3597. https://doi.org/10.3168/jds.S0022-0302(91)78551-2.

Waghorn, G. 2008. Beneficial and detrimental effects of dietary condensed tannins for sustainable sheep and goat production-Progress and challenges. Anim. Feed Sci. Technol. 147:116-139. https:/ /doi.org/10.1016/j.anifeedsci.2007.09.013.

Waghorn, G. C., I. D. Shelton, W. C. McNabb, and S. N. McCutcheon. 1994. Effects of condensed tannins in Lotus pedunculatus on its nutritive value for sheep. 2. Nitrogenous aspects. J. Agric. Sci. 123:109-119. https://doi.org/10.1017/S0021859600067836.

Wang, Y., G. C. Waghorn, W. C. McNabb, T. N. Barry, M. J. Hedley, and I. D. Shelton. 1996. Effects of condensed tannins in Lotus corniculatus upon the digestion of methionine and cysteine in the small intestine of sheep. J. Agric. Sci. 127:413-421. https://doi .org/10.1017/S0021859600078576.

Wattiaux, M. A., and K. L. Karg. 2004. Protein level for alfalfa and corn silage-based diets: II. Nitrogen balance and manure characteristics. J. Dairy Sci. 87:3492-3502. https://doi.org/10.3168/jds .S0022-0302(04)73484-0

Woodward, S. L., M. J. Auldist, P. J. Laboyrie, and E. B. L. Jansen. 1999. Effect of Lotus corniculatus and condensed tannins on milk yield and milk composition of dairy cows. Proc. N.Z. Soc. Anim. Prod. 59:152-155.

Zanton, G. I. 2016. Analysis of production responses to changing crude protein levels in lactating dairy cow diets when evaluated in continuous or change-over experimental designs. J. Dairy Sci. 99:4398-4410. https://doi.org/10.3168/jds.2015-10438.

\section{ORCIDS}

M. J. Aguerre $\odot$ https://orcid.org/0000-0001-6205-8601

M. A. Wattiaux @ https://orcid.org/0000-0001-8713-1641 